\title{
CSR Practices by Private University-A Study on Leading University Sylhet, Bangladesh.
}

\author{
Farhad Hossain \\ (Senior Lecturer, Business Administration, Leading University Sylhet, Bangladesh)
}

\begin{abstract}
The main purpose of doing business for any organization is to earn profit. But only profit motive does not make a firm or organization long term sustainable. Now- a- day's organization does not only busy with profit making but they are more concern for social development also. In that case as an institution education sector also not sit idle they are also involve in social development. They think themselves as a valuable member of the society. As are doing their business activities within the society and the entire stakeholder are from society, so it is impossible to ignore their contribution. The aim of this paper is to explore how academic institutions practices Corporate Social responsibilities in Bangladesh. For this Leading University has been chosen in this case because it does not only provide the quality education and fulfill the academic needs not only in Sylhet but also across the Sylhet. Leading university think along with providing quality education, social development is essential. In keeping with global evolution CSR has gained a lot of attention. It is one of the important mechanisms that affect society positively and develop relationship with stakeholders. CSR not only help leading university to gain the competitive advantages but also help to gain good image. As well as students also gain practical experience of their study of CSR course.
\end{abstract}

Keywords: CSR, University, Private, Society

\section{Introduction}

Today's world is very competitive. To survive in the long run for any organization is not so ease. Nowa-days, organizations are doing business not only for making profit but also they invest small portion of their profit for social welfare. This is the corporate social responsibility for any organization. Many organizations are now doing CSR activities. They can realize that it not possible to sustain for long period of time without social welfare. They also think that they are the part of the society. They have some responsibilities toward the society where they doing business. Now there is a great competition in education sector also. Universities, especially private ones are in need of strong corporate strategies in order to be successful in the highly competitive education industry. In this respect, Corporate Social Responsibility (CSR) becomes one of the highly preferred strategies by higher education institutions for gaining a good reputation and a competitive advantage. All the universities both private and public have the main motive is to provide quality education and make future leader. But private university does not get any financial benefit from government. They have to do the operation by using their own fund that collected from the students as different fees. So sometimes it is difficult for them to do social activities because of having some constraints. Nevertheless some universities pay attention to the society development; they involve CSR activities apart from their regular business. They think that it is their social obligation.

\section{Concept of CSR}

A lot of definition are available that define Corporate Social Responsibility (CSR). CSR can be defined as an approach that contributes to sustainable development by delivering economic, social and environmental benefits for all stakeholders. It is the concept where organizations incorporated social and environmental concern into their business operation and interface with the stakeholder. CSR is defined as the economic, legal, ethical, and discretionary expectancies that society has of organizations at a given point in time (Valentine and Fleischman 2008). CSR can be broadly defined as the activities making companies good citizen who contribute social welfare beyond their own self interest (Bahman, Kamran and Mostafa 2014).

\section{Methodology}

Leading university plays CSR activities under their Social service Club named Leading University Social Service Club (LUSSC). This study has been conducted primary and secondary data. Primary data has been collected through the interview of the official staff and the advisors of LUSSC and the member of LUSSC. Secondary data has been collected through the books, journal and Boucher of Leading University. Data also collected from different beneficiaries. After collecting this data this has been cross check. 
The main purpose of this study is

\section{Objectives}

- To analyze the CSR practices of Leading University.

- To identify the area where leading University operates CSR activities.

- To identify the gap where they should invest for CSR purpose

- To identify the reasons that university should involve CSR activities.

\section{CSR In Private University}

Maintaining stakeholder is a key factor for long term sustainability. To make a balance among the stakeholders is a crucial task. The main stakeholders of the university are students, bank, government, employees, governing bodies and suppliers. University is expected not only economic profit oriented, but it should concern with environmental sustainability (planet) and the welfare of society (people). University should also give more attention to the interaction and impact of its activities to all stakeholders. Here given the chart of stakeholders of an university at a glance. Stakeholders play a key role in corporate social responsibility (Bearle and Means, 2002; Costa and Menichini, 2013; Murray and Vogel, 1997 Publishers, 2002. According to Freeman`s theory a stakeholder is anyone susceptible to be impacted by the goals of an enterprise and anyone that could be impacted by their realization (Freeman 2010). Privatization of the education institutions and competition in higher education industry, many higher education institutions are struggling in order to compete and survive in the changing face of the industry (Gumport 2000, Gioia and Thomas 1996).

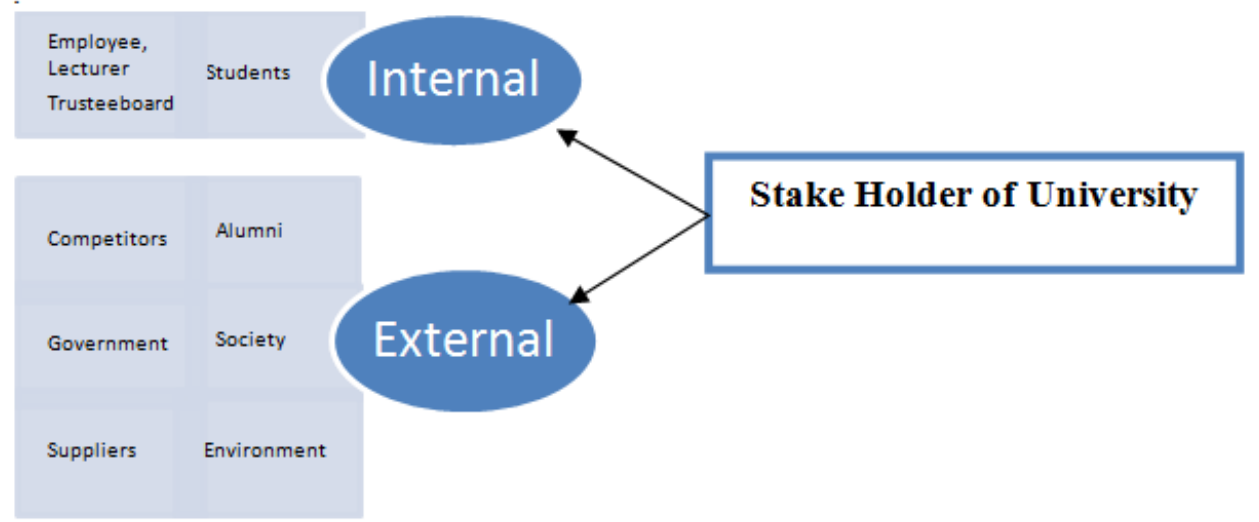

Fig: Stakeholders of University.

\section{Importance Of CSR}

To involve in CSR practice helps an organization a lot. It has a long term impact. Customers always prefer to purchase product from ethical organization. For the student, academic learning is not enough to success, they also need practical experience. Through CSR they can get hand to hand teaching on doing ethical business. Today's world just not only involves doing business. They have to business ethically. Here given some causes why an organization joins in CSR activities.

The top ten reasons for engaging with CSR are given below as defined by CSR network and Yeldar (2005).

\section{1) Increased profit}

Several academic studies have shown a direct correlation between socially responsible business practices and positive financial performance:

- Some of founds shown that, companies/organizations with a defined corporate commitment to ethical principles do better financially (based on annual sales/revenues) than companies that don't.

- "Stakeholder-balanced" companies showed four times the growth rate and eight times the employment growth when compared to companies that are shareholder-only focused during 11-year at Harvard University as an study founds.

\section{2) Access to capital}

Companies/ organizations that are committed to CSR often have access to capital that would not otherwise be available, due to the increase in Socially Responsible Investment (SRI). A 2001 study showed that 
$12 \%$ of total investment in the USA was of a socially responsible nature. Likewise, there were 313 green, social and ethical funds operating in Europe in June 2003, showing a 12\% increase in the last eighteen months.

\section{3) Reduced operating costs/increased operational efficiency}

Contrary to widely-held opinion, improved environmental management systems do not automatically result in greater cost. Over time, they improve operational efficiency by reducing waste production and water usage, increasing energy efficiency and in some cases, selling recycled materials. There are also company specific ways of reducing operating costs. By considering impacts, a company's/ organization's actions can result in environmental, social and economic benefits.

\section{4) Enhanced brand image and reputation}

A good reputation is often very hard to build - and yet can be destroyed in less than a day. So much of a company's / organization's reputation results from trust by stakeholders. A strong reputation in environmental and social responsibility can help a company build this trust. However, it needs to result from real practices and policies and integrity towards the companies responsibilities. Stakeholders are not stupid and can see through fluff'. Non Government Organizations (NGOs) and local communities are far more willing to not take action as a result of an environmentally-damaging incident if it is evident that the company has genuinely worked hard to prevent it happening in the first place, and has in place solid management practices for rectifying the situation quickly - and for learning and improving to prevent an repeat occurrence.

\section{5) Increased sales and customer loyalty}

Research has shown that consumers not only want good and safe products, but they also want to know that what they buy was produced in a socially and environmentally responsible way. CSR can lead to new University and it's studends lines.As Dr Steckel and Simons pointed out in their book Doing Best by Doing Good'and -The National Trust benefits by receiving operating income from the royalties.

\section{6) Increased productivity and quality}

Business for Social Responsibility is a membership organization based that helps companies / organizations improve their CSR learning, management and activities. Main mentality points out —Company efforts to improve working conditions lessen environmental impacts or increase employee involvement in decision-making often lead to increased productivity and reduced error rate. For example, improve working conditions and labor practices among their suppliers often experience a decrease in merchandise that is defective or can't be gain

\section{7) Increased ability to attract and retain employees}

A company's/ organization's dedication to CSR can help to attract and retain employees. People want to work for an organization that is in accordance with their own values and beliefs. Employees are not just worried about promotion and salary any more. According to the experiences; Launched Values in Action programmed which aligns the business objectives with sustainable development, having seen a 5\% drop in staff turnover. Again generally, $78 \%$ of employees would rather work for an ethical and reputable company than receive a higher salary

\section{8) Potentially, reduced regulatory oversight}

The more a company/ organization shows it is committed to CSR by complying with and going beyond legislation, the more lenient governments and regulators may be with the company. They may be given preferential treatment when applying for permits or permission to do something, and if an accident occurs, will be regarded more favorably if they have been transparent and socially responsible in the period running up the accident/incident.

\section{9) Reducing risk, and increased risk management}

The more a company / organization is committed to CSR, the less they are exposing themselves to business risk. This could be reputational risk following bad press, e.g. the highly publicized, financial risk or environmental risk. Fund Management companies are becoming more vocal and assertive about their own expectations regarding a company's organization's evidence of responsibility in order to reduce risk.

\section{0) 'Keeping up' with competitors and where the educational platform is.}

This is where business/ education are heading: the world over, regardless of the regional culture. Coming to mind immediately when discussing whether and how companies / organizations are embracing the 
concepts of corporate social responsibility. There are others. For all, the starting points are often different, some are driven by regulations and legislation and others are driven by self-regulation. Governments, investors, local communities and suppliers are all putting pressure on companies / organizations to live up to their expectations of an organization in society and in the environment.

\section{Literature Review}

There are a number of CSR researchers who have written articles about the societal perspective A lot of research has been conducted on CSR. But CSR practices by the university found rare. Hare given some findings done by different scholar. Concept is also applied to maximize university's benefits to stakeholders and minimize the negative impact of university's activities to stakeholders. Bowen (1953) Argues that firms need to be cognizant of business ethics to achieve long term superior performance. CSR activities provide an "insurance-like" protection when negative events happen (Godfrey et al. 2009). According to Maignan and Ferrell (2004), there are two main motivations of organizational. CSR activities concerning stakeholderrelations: the first one is the instrumental approach. The other one is from the moral perspective. Aguilera et al. (2007) suggest that corporate social behavior is driven by instrumental, relational, and moral motives. Furthermore, partly based on organizational justice Consumers may be a significantly important component in the corporate context, since consumers' satisfaction mediates the association of CSR actions with market value (Luo and Bhattacharya 2006). Carroll (1979) identifies the CSR pyramid, which includes four stages of CSR development: economic, legal, ethical, and philanthropic obligations. Responsible higher education practices not only contribute to the well-being of the shareholders and the public in general, but also these practices will increasingly become a long-term value proposition for the institution itself (H.Kashyap, 2014).

\section{Why Should University Involve CSR Practices}

CSR helps an institution build a reputation in different ways; it helps attract socially conscious students and improves the acceptability of the school among the local communities. For smaller institutions that do not have the resources to compete with larger institutions, CSR can be a major differentiating point. A small institute that focuses on CSR and sustainability may be able to attract better faculty, students and recruiters. University is expected not only economic profit oriented, but it should concern with environmental sustainability (planet) and the welfare of society (people).

University should also give more attention to the interaction and impact of its activities to all stakeholders

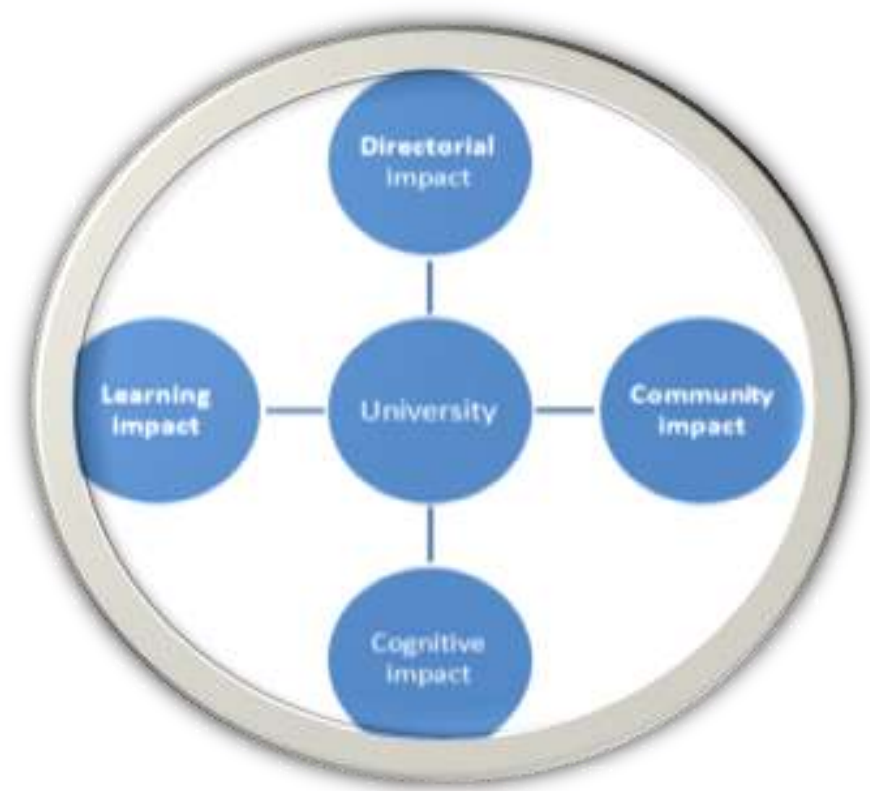

Here given the detail task of impact factor by the university. 


\begin{tabular}{|c|l|}
\hline \multicolumn{2}{|c}{ CSR Implementation Concept for Each Impact } \\
\hline \multirow{3}{*}{ Community impact } & $\begin{array}{l}\text { Through community participation in mutually beneficial cooperation through various } \\
\text { development efforts. Providing health care, education and the arts for the community } \\
\text { surrounding the campus. Providing direct contribution in the form of donations to } \\
\text { those who urgently need, such as victims of natural disasters. Encouragement SME } \\
\text { businesses run by the people around the university premises. }\end{array}$ \\
\hline \multirow{5}{*}{ Learning impact } & $\begin{array}{l}\text { Preparing students to become accountable nation in sustainable progress. To provide } \\
\text { scholarships to students. To campaign changes of student's behavior relating with } \\
\text { some issues, such as anti corruption, public health, environmental conservation, } \\
\text { against drug use and against terrorism. }\end{array}$ \\
\hline The social responsibility for application of university's technical and scientific \\
activities. Implementing Transparency in University management practices. \\
Implementing business practices that are environmentally friendly. Ethics as a \\
mandatory subject in every faculty of LU. LU also practices Good University \\
Governance
\end{tabular}

\section{Areas Of CSR Practices In Education Sector}

In educational sector, different areas of CSR practices are discussed below:

1) Courses design must relate to social responsibility subject: Academic institutions should design the courses about social responsibility subject open to students, teachers and personnel to promote human rights and social values and ethics.

2) CSR towards Stake holders: CSR activities should cover collaborations among stakeholders like students, parents, ex- students, organizations and government departments.

3) Recycling of Wasted papers: Students can be trained to use the wasted which can be distributed to local foundation for their self earning.

4) CSR at Workplace : It includes the activities commonly attempt to maintain high standards of recruitment, selection, development and retention of employees, health, safety and welfare, wellness programmes, employee training and employees ${ }^{\text {ee }}$ communication channels. Other activities encourage originality for green business and technology.

5) CSR on society: It focus on investment to communities such as contribution of money, technology, experts, time, services and other resources to make a positive input towards local communities. Academic institutions should contribute social and educational supportive activities for women, children and youth, who maintain underprivileged to near area.

6) CSR through establishing study Center: Academic institutions should conduct scientific research, training and professional programs, publications and documentation of the social, economic and cultural development of the society by establishing research center.

7) CSR on atmosphere: It covers the actions to diminish the utilization and waste and to create further understanding on the importance of conserving and caring the environment. For example awareness programs about green cities or cleanliness, conservation of forest, reduce pollution and sustainability of the environment.

\section{CSR Practices By Leading University}

As an academic institution Leading University is the example for its CSR activities in Sylhet. The authority of Leading University invests a lot of money for CSR activities. Whole of the year they are busy with CSR actions along with other academic activities. It creates a lot of opportunity of employment. There are some clubs exist in this University. One of the prominent clubs is Leading University Social Service Club (LUSSC). They are responsible for all social activities under the banner of Leading University. The following activities usually done by this university.

Health care program: The social service club of leading university does a lot of health care programs every year. Here given the details of the activity

Blood donation: Every year LUSSC arrange blood donation camp in the university premises. They also create awareness to the mass that regularly donation of blood makes a person healthy and also help others who require blood. From the blood donation camp people can easily know their blood group and also free checking of blood diseases. 
Dental camp: Free dental checkup is another program that LUSSC done every year. Here the students, staff and teachers are invited to checkup their teeth without cost.

Free health checkup: Free health checkup is another program that LUSSC takes initiatives. Here normal health related advices are given to the teacher, students and staff. Normally here blood pressure, diabetics and other normal checkup are done.

Social awareness: LUSSC also takes initiatives for social awareness program like conduct rally on different special day such as Tobacco free day, say No to drug, Discourage early marriage and other social awareness program

Free zebra crossing: LUSSC also make Zebra crossing in front of the university to ensure the safety of the pedestrian.

Awareness creation of against terrorism: Recent Leading University also takes initiatives for creating against terrorism. They arrange rally against terrorism, make debate competition subject to against terrorism.

\section{Environment}

Tree plantation: As a part of this society leading university also think it has some responsibilities toward society. To minimize pollution LUSSC also go for tree plantation.

Clean environment awareness program: the students of leading university not only busy in their study but also busy to keep their surrounding cleans. For this they take a lot of initiatives to create awareness to the society

\section{Society development program}

Alo school for underprivileged children: This is a great job that leading university done. Under LUSSC a school has been setup where underprivileged orphan child get the opportunities to study free of cost. The members of LUSSC take class of this orphan child without any cost. They also supply study materials with free of cost. Ramadan Iftaar for street children. Warm cloth distribution for poor people at winter. Art competition arrangement. Collection money for any sick person

\section{Corporate Social Responsibility by Leading University At a glance.}

\begin{tabular}{|l|l|}
\hline Sector & Area of CSR \\
\hline Health & $\begin{array}{l}\text { Free dental camp } \\
\text { Health care camp } \\
\text { Blood donate campaign }\end{array}$ \\
\hline Free eye diseases treatment \\
Restoring Environment & Clean environment campaign \\
& Tree plantation \\
\hline Social awareness & Rally against terrorism \\
\hline $\begin{array}{l}\text { Social development } \\
\text { Road safety } \\
\text { Design to course }\end{array}$ & $\begin{array}{l}\text { School run by LUSSC name Alo school for orphan } \\
\text { children. }\end{array}$ \\
\hline CSR at workplace & Ramadan Iftaar with street and orphan children \\
\hline & Free education material provide \\
\hline
\end{tabular}

\section{Conclusion}

Although Leading University doing a lot to promote social awareness along side with their regular activities. It has become a good example in a little urban city Sylhet, Bangladesh. But as a private university it also has some limitation, though it has great intension to do immense task for the development of the society. It is expected the other private university also come forward by taking Leading University as a role model.

\section{References}

[1]. Valentine, S. and Fleischman, G. (2008). Professional Ethical Standards, Corporate Social Responsibility, and the Perceived Role of Ethics and Social Responsibility. Journal of Business Ethics 82, 657-666.

[2]. Bearle, A. and Means, G. (2002) The Modern Corporation and Private Property. 4. print. New Brunsvick: Transaction

[3]. Freeman, E. (2010) Strategic Management: A Stakeholder Approach. Cambridge: Cambridge University Press.

[4]. Gumport, P. J. (2000). Academic Restructuring: Organizational Change and Institutional Imperatives. Higher Education 39, 67-91

[5]. Maignan and Ferrell (2004), Corporate social responsibility and marketing: An integrative framework Journal of the Academy of Marketing Science December 2004, Volume 32, Issue 1, pp 3-19 
[6]. Godfrey PC, Merrill CB, Hansen JM. 2009, The relationship between corporate social responsibility and shareholder value: an empirical test of the risk management hypothesis. Strategic Management Journal 30(4): 425-445.

[7]. Aguilera, R., Rupp, D. E., Williams, C. A., \& Ganapathi, J. 2007. Putting the s back in corporate social responsibility: A multilevel theory of social change in organizations. Academy of Management Review, 32(3): 836-863

[8]. Heena Kashyap (2014), "Corporate Social Responsibility Towards Education in India”, Research Directions, Vol.1, Issue 12, ISSN :2321-5488

[9]. Bowen (1953) Book- The Social Responsibilities of the Businessman

[10]. Radley, Y. 2005. The Top 10 Benefits of Engaging in Corporate Social Responsibility: The Business Case (Sub-titled _Why Bother with CSR')? Reported by; csrnetwork and Yeldar Radley, pp:1-4

[11]. Hartomo, University Social Responsibility: The Implementation Of University's Caring For God's Creation

[12]. Pour.B, Nazari, K and Emami, M (2014) .Corporate Social Responsibility-A literature Review.Arfican Journal of Business Management vol.8(7): pp 228-234 